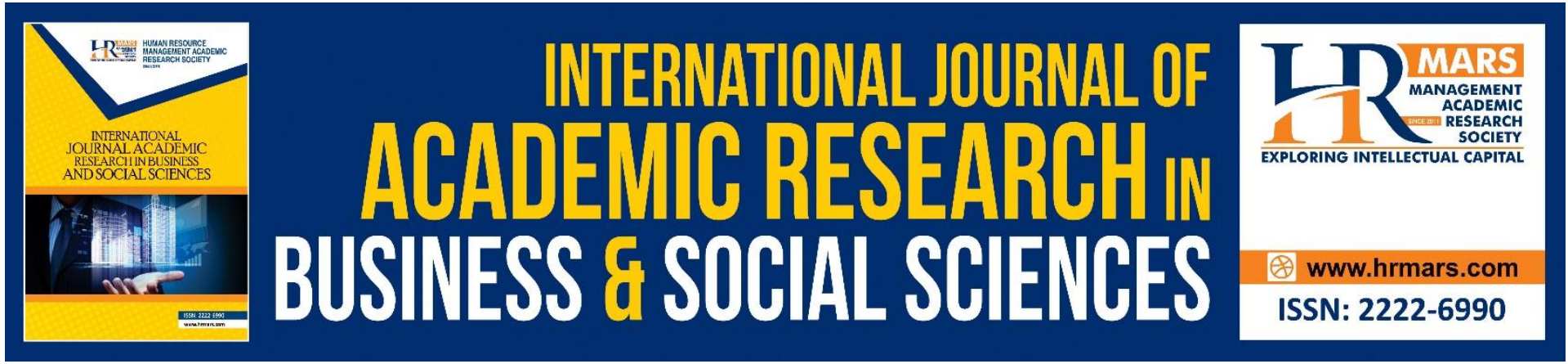

\title{
Dynamics of Land Use Changes on The Livelihoods of The Local Communities in Baringo County: Understanding The Drivers
}

Edward Lekaichu Ole Kateiya, Aggrey Daniel Maina Thuo, Maurice Ochieng Ombok

To Link this Article: http://dx.doi.org/10.6007/IJARBSS/v11-i9/11038

DOI:10.6007/IJARBSS/v11-i9/11038

Received: 14 July 2021, Revised: 16 August 2021, Accepted: 30 August 2021

Published Online: 09 September 2021

In-Text Citation: (Kateiya et al., 2021)

To Cite this Article: Kateiya, E. L.,Thuo, A. D. M., \& Ombok, M. O. (2021). Dynamics of Land Use Changes on The Livelihoods of The Local Communities in Baringo County: Understanding The Drivers. International Journal of Academic Research in Business and Social Sciences, 11(9), 560-591.

Copyright: @ 2021 The Author(s)

Published by Human Resource Management Academic Research Society (www.hrmars.com)

This article is published under the Creative Commons Attribution (CC BY 4.0) license. Anyone may reproduce, distribute, translate and create derivative works of this article (for both commercial and non-commercial purposes), subject to full attribution to the original publication and authors. The full terms of this license may be seen at: http://creativecommons.org/licences/by/4.0/legalcode

Vol. 11, No. 9, 2021, Pg. 560 - 591

Full Terms \& Conditions of access and use can be found at http://hrmars.com/index.php/pages/detail/publication-ethics 


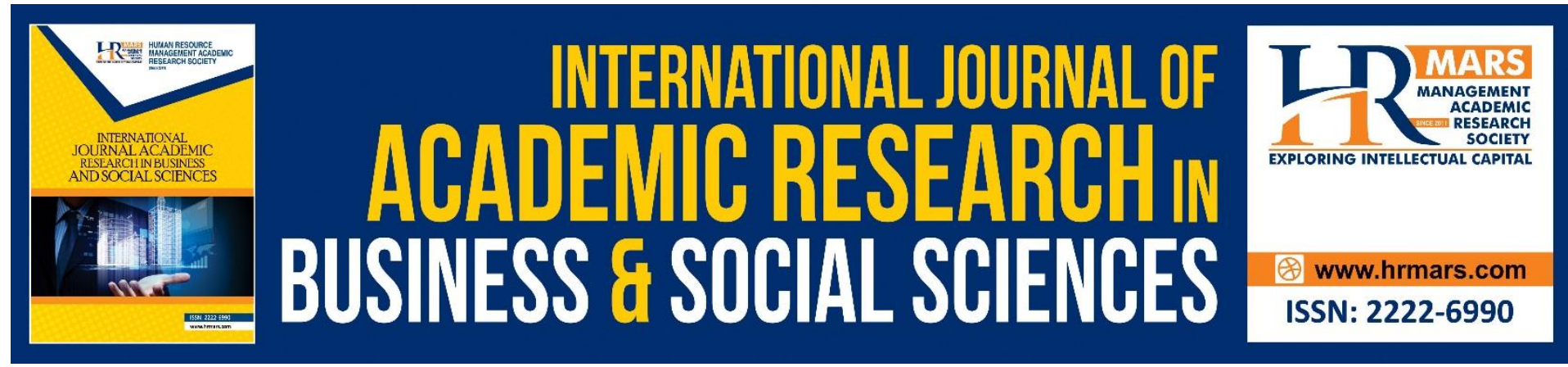

\title{
Dynamics of Land Use Changes on The Livelihoods of The Local Communities in Baringo County: Understanding The Drivers
}

\author{
Edward Lekaichu Ole Kateiya \\ School of Business and Economics, Maasai Mara University, Kenya.
}

Prof. Aggrey Daniel Maina Thuo, PhD

School of Natural Resources, Tourism and Hospitality, Maasai Mara University, Kenya.

\author{
Dr. Maurice Ochieng Ombok, PhD
}

School of Business and Economics, Maasai Mara University, Kenya.

\begin{abstract}
This paper examined the dynamics of land use changes on the livelihood of the local communities in Baringo County. Land is a principal factor of production, a source of life and livelihoods. It provides a means of living and a variety of uses such as agricultural, human settlement, environmental conservation, urban and industrial development purposes among others. These uses compete for space in a fixed area, hence the rising land use conflicts and degradation. The situation has threatened lives and livelihoods, making it difficult to plan for the livelihood activities in the County. This is happening against the backdrop of land use policy changes including; sessional paper no 3 of 2009 on the National Land Policy, the Constitution of Kenya 2010, the Land Act, 2012, the Land Registration Act, 2012, the Community Land Act, 2016 and sessional paper no 1 of 2017 on National Land Use Policy that were intended to alleviate the situation. This situation is now a major threat to the livelihood of the local communities in Baringo County. This study, therefore, sought to examined the dynamics of land use changes on the livelihood of the local communities in Baringo county with specific objective to establish the drivers of the changes. A comprehensive desk review of existing literature was done, and land use changes were descriptively analyzed. The review spanned from pre-colonial (before 1895), colonial (1895 to 1963), independence (1963 to 2010) including the subsequent years of land reforms following the promulgation of the Constitution of Kenya 2010 onwards to 2020. The study found that the key drivers of land use changes originate from the change of land use policies from customary to European-like systems during the colonial era (1895 to 1963). These drivers revolve around the conflicts in the application of land use policies and laws, dual production system (different land use for registered private land in arable areas and the unregistered community land in non-arable areas within the county) occasioning wide productivity gap and economic disparity. Further the knowledge gaps associated with colonial perceptions, ideologies, and attitudinal
\end{abstract}


practices, which led to misconception and wrong policies aggravated the situation. The consequences disorganize the local community land use and social system, broke down the traditional grazing and cropping patterns, depleted soils fertility \& degraded the environment. In addition, the study found out that in the unregistered community land, land use conflicts were rampant, and characterized by invaded and claim interest as well as unscrupulous legal manipulation of land ownership records leading to dispossession. These two salient features are the main drivers of land use changes that led to continuous and frequent fatal inter-ethnic land use conflicts among the local communities; causing displacement and destruction of property among other atrocities working against politically weak local community. This scenario destabilized livelihood possibilities making it difficult for local communities to engage in basic livelihood activities and create uncertainty for future development. The study concluded that the security of land tenure perpetrates land use conflicts particularly in the unregistered community land. The government, therefore, need to register the community land to enhance land tenure security in the county.

\section{Background of the Study}

The background of the study covers introduction, problem statement, objectives

\section{Introduction}

Globally, land resource is the basis of human livelihood, since it provides basic needs such as food, water, energy, clothing and shelter. It allows for a variety of uses including agricultural production, human settlement and environmental conservation to preserve it for posterity, and can satisfy a diverse range of local communities' livelihood objectives. All these uses of land resource compete for space in a fixed land area within an ever-changing environment. In addition, it is a finite resource and increasingly becoming scarce over time. The ensuing competition and growing forces at work necessitates government intervention through land use policy in order to harmonize the various uses. Moreover, in practice, it is difficult to arrive to an equilibrium between the various uses without an external force. Therefore, the unfolding scenario leads to land use changes problems, which calls for government intervention through land use policies. Land use policy is intended to balance users demands, facilitate production and sustain livelihood for the local communities and at same time guarantee political stability. In this study, dynamics of land use changes is defined as policy changes and the resultant consequences.

In Africa, dynamics of land use changes evolved through various transformations associated with government policies adopted by different political regimes. The changes were traced from the pre-colonial, colonial and post-colonial eras. Each of these eras introduced changes in land use policies that shape up different social, economic and political realities on the livelihood of the local communities. Livelihood is defined as comprising the capabilities, assets (including both material and social resources) and activities required for a means of living by the local communities (Scones, 2008). Livelihood is sustainable when it can cope with the policy changes, and recover from, stresses and shocks arising from it, maintain or enhance local communities' capabilities, assets and activities, while not undermining the natural resources base. In this case, land resource represents the natural resource base, and the capacity of the local communities to use it to generate and maintain their means of living, enhance their well-being and preserve it for future generations is dependent on policy changes. These changes influence greatly the livelihood outcomes of the local communities. 
In this respect, local communities are indigenous populations who reside and derive their livelihood from land resource. They consider land resource as the principal factor of production and the source of livelihood because it provides basic needs such as food, water, energy, clothing and shelter. Land resource also allows for a variety of uses including agricultural, human settlement and environmental conservation that satisfy a diverse range of livelihood objectives for local communities.

In Kenya, dynamics of land use changes emanates largely from colonial regime actions and policies, which continued in slightly modified manner after independence (Thuo, 2013). Before the colonial era (before 1895), land use was managed through African local communities' customary laws. Land use and management practices were guided and controlled by established regulations and procedures among various local communities (Thuo, 2013). Land use was organized into specific areas of agricultural (crops and livestock), human settlement, environmental conservation uses and heritage sites, among others. Most of the land resource was owned by the entire community while individual community members had only user rights (Thuo, 2013). The land use was communal, small-scale subsistence in nature, stable and sustainable in terms of provision for local communities' livelihood and environmental conservation needs. The period depicts a close economy without government intervention in terms of land use policy changes. Local communities enjoy territorial niches with boundaries defined by specific geographical and physical features such as rivers, mountains, trees, and valleys. The ethnic community chiefs, assisted by the Council of elders, had the power to make land use decisions. Land use was assumed to operate in a dynamic equilibrium checked by raids and natural disasters such as war, disease outbreaks, earthquakes and famines. Soil fertility was maintained through shift cultivation with adequate fallow periods of three (3) years or more required to restore soil structure and fertility. Much of the uncultivated land was used as pastoral communities grazing areas. Forested areas were used for hunting, trapping and honey gathering. Periodic droughts checked Land use and inter communities' raids to maintain the dynamic equilibrium.

During colonial era(1895 to 1963), the colonial government took over the control of land use from the local communities through violence, trickery, and mutual agreements (Thuo, 2013). It dismantled the ethnic community territorial niches and nationalized land use. All land in Kenya became Crown Land. All local communities were dispossessed, and customary land use laws by the local communities were rendered redundant. All existing land use rights by the local communities were at the mercy of the colonial power (Okoth-Ogendo, 1995). Therefore, the genesis of land use problems in Kenya. Fundamentally, the land use policy changes were biased and oriented to benefit European settlers with scant attention to local communities. The land use policies created a dual land use system where the European colonists occupy the high rainfall and fertile areas, employing modern land use practices based on individuals' decisions. At the same time, the local communities were restricted to native reserves in the drier regions, where local communities were allowed to continue with collective land use decisions. These land use changes promoted economic disparity between European settler and local communities during colonial era. Land use policies promoted high productivity land use practices for European white farmers, while encouraging low productivity traditional land use practices for local communities. The land use policy changes brought about the breakdown of social security, escalated trans-generational land rights and created tension and insecurity, disrupted social organization of local community and resulted to a situation of landlessness among the local communities. The dynamics propagated unsustainable livelihoods for the local communities leading to the struggle for independence. 
At independence in 1963, and subsequent years after independence to 2010, the independent government of Kenya focused on redistribution of land resources, settling and resettling local communities in areas previously occupied by European settlers (Syagga, 2006). Land use policies retained the colonial system. The primary target was to transfer land use structures from former colonial rule to independent African governments. The land use policies maintained agronomic arguments in the colonial system. Many sectoral laws were formulated and enacted, each dealing with specific and scattered land use problems, including the Agriculture Act (Cap 318), the Forest Act (Cap 385), the Plant Protection Act (Cap 324), the Water Act (Cap372), and the Grass Fire Act (Cap 327) among others. All these acts aim to address historical and social inequalities experienced colonial era with respect to the various aspects of land use. Coincidently, most of the anticipated land use changes after independence were not realized, primarily because of malpractices in government (Khamisi, 2018). Khamisi argued that since 1963, the land use changes were placed under the executive mandate of the presidency. The presidency was tasked to initiate the resettlement program. The settlement schemes were massively affected by corruption from the presidency, local politicians, elites, and businessmen (Khamisi, 2018). The period was characterized by illegal allocation and land grabbing. Instead of addressing land use problems, elites and government officials took advantage of the situation and inherited European farms, and continued using bias land use policies under the principles laid down in the colonial system. Indeed, the independent government of Kenya maintained the dual land use system previously used by the colonial government, which reinforced economic disparities, and bred a new paradigm shift of economic marginalization along ethnic lines and political domination among the local communities. Land use malpractices continued to accelerate land use problems. These trends seemed to be chronic, and continue to encourage land use malpractices. This scenario was aggravated by skewed takeover of farms previously owned by European settlers by elites and politically correct individuals in government referred as "elite capture". Th elite capture triggered a spiral of land use problems including land fragmentation, environmental degradation, depletion of forest cover and destruction of water catchments among others. This scenario and the dynamism inherent in the process triggered land reforms. These reforms are reactive in nature and driven by foreign ideologies without consideration of local communities' experiential knowledge on the environment. Moreover, in most cases, experience show that government land use policies were only on paper but not applicable on the ground.

Otherwise, land use reforms efforts took a different twist when introducing the Constitution of Kenya 2010. Under the constitution of Kenya 2010, land use reforms focused on implementing the various recommendations, including those made by the Njonjo and the Ndungu commissions, several other studies, and taskforces. The recommendation focuses on solving land use problems in Kenya. The main aim was to accelerate the pace of land use reforms in Kenya. Indeed, significant milestones have been realized include: enactments of Sessional paper No 3 of 2009 on the National Land Policy, the promulgation of the Constitution of Kenya in August 2010. The Constitution under Article 60 prescribes that land in Kenya be held and managed in an efficient, productive, and sustainable manner. The Constitution classifies land into three categories, that is, Public, Private, and Community Land. In this respect, Article 67 creates the National Land Commission to manage Public Land, among other functions and mandated the parliament to legislate land laws by revising, consolidating, and rationalizing existing land laws. This enactment includes:

i) Land Act, 2012; the Act provides a framework for revising, consolidating, and 
rationalizing Kenya's previous land laws and sustainable land use and land-based resources. The Act further provides the establishment of settlement schemes to provide access to land for shelter and livelihood.

ii) The National Land Commission Act, 2012; Act mandated NLC to manage public land on behalf of the National and County governments.

iii) The Land Registration Act, 2012 provides the framework for the registration of title to land in Kenya and gives effects to the principle and objects of devolved government in land use and management.

iv) The Community Land Act, 2016; Act provides for the recognition, protection, and registration of community land rights; management and administration of community land; specified the role of county governments concerning unregistered community land, and for connected purposes.

v) The National Land use policy Sessional paper no 1 of 2017; provide a legal, administrative, institutional, and technological framework for optimal utilization and productive use of land resources sustainably and desirably at national, county, and community levels. The fundamental principles of the policy include efficiency, access to land use information, equity, elimination of discrimination, and public benefit sharing. The approach emphasizes key measures of sound land use practices, conservation and enhancement of land -and land-based resources, and the proper management of demographic and health parameters to ensure efficient, productive, and sustainable land use.

Despite the highlighted government interventions embodied with enormous legal support, land use problems continued to rise at an alarming rate. Land use changes in Kenya from the colonial era through subsequent years after independence maintained a policy framework that have done little to unravel the many land use problems affecting the livelihood of the local communities, especially in the rural and drier areas of the Country (GoK, 2016- National Spatial Plan 2015-2045). Indeed, land use policy decisions and responses to consequences have been centralized at the national level. However, recent land use reforms through the Constitution of Kenya 2010, the Kenya Vision 2030, and the sessional paper No 3 of 2009 on National Land Policy advocates for decentralization of land use and its governance to the Counties, no significant change on the livelihood of local communities in the rural areas has been realized so far. In fact, land use conflicts are increasing at an alarming rate.

In Baringo County, the dynamics of land use is guided by the national policy framework, and greatly influenced by climatic, cultural beliefs and altitude. Baringo county has a total land area of $11,035 \mathrm{~km}^{2}$ of which $4,435 \mathrm{~km}^{2}$ arable, 5,700 $\mathrm{km}^{2}$ non-arable, $715 \mathrm{~km}^{2}$ urban lands, and others purposes (CIDP, 2018). Based on these statistics, the arable land area constitutes $40.19 \%$ of the total land area and comprises mainly highlands covering higher elevations of the County. This area is within the modified tropical zones with soils that are generally welldrained and fertile. This zone receives an average rainfall of $1000-1500 \mathrm{~mm}$ per annum and temperatures range from a minimum of $10^{\circ} \mathrm{C}$ to a maximum of $28^{\circ} \mathrm{C}$. This area is considered to be a high potential for agricultural and improved livestock development. The livelihood activities comprise mainly crop farming, including food crops like cereals (maize \& Beans), fruit trees and horticultural crops, and cash crops such as coffee, which is grown in small scale additional livelihood activity.

On the other hand, non-arable land in Baringo County constitute $51.65 \%$ of the total land area. It covers lowlands made up of semi-arid to arid climatic regions receiving an average 
rainfall of $600 \mathrm{~mm}$ per annum with temperatures ranging from a minimum of $28^{\circ} \mathrm{C}$ to a maximum of $40^{\circ} \mathrm{C}$, has complex soils with various textures and drainage conditions which have developed from alluvial deposits. Some of these soils are saline. Shallow stony sandy soils characterize a large area with rock outcrops, volcanic ash, and lava boulders. This zone is a rangeland with isolated dryland subsistence agriculture pockets and small-scale irrigation in Marigat -Baringo South, Barwessa - North Baringo, and Kolowa -Tiaty Constituencies. The area is characterized by recurring droughts (see appendix I). In three decades (1984 to 2000), particularly in Marigat area, satellite images indicate that the drought trends increased in intensity, and the rate of vegetation depletion was gradually decreasing, leading to increased bare soils and rocks and dwindling water bodies. The remaining area covers urban areas and lands under other competing land uses. Land use in Baringo county has undergone several lands uses changes. These uses include agriculture, pastoralism, human settlement, vegetation cover, and water bodies (CIDP,2018).

Past studies (Ochuka et al., 2019), indicates that in the last three decades from 1988 to 2018, land use changes in Baringo County show increased agricultural land use by $21.11 \%, 24.33$ $\%$, and $26.03 \%$, decreased pastoralism land use by $15.14 \%, 19.27 \%$, and $23.01 \%$, increased human settlement land use by $2.22 \%, 1.43 \%$ and $2.47 \%$, decreased the vegetation cover by $1.75 \%, 2.79 \%$, and $3.78 \%$, decreased water bodies by $2.77 \%, 3.23 \%$ and $1.66 \%$, in the 1988 1998, 1998-2008 and 2008-2018 periods respectively. These trends indicates that agricultural land use increases at an increasing rate, pastoralism decreases at an increasing rate, human settlement increase at an increasing rate, vegetation cover decreases at a rising rate, and water bodies decrease haphazardly. Therefore, it poses a worrying concern that threatens the sustainability of land use changes on the livelihood of the local communities.

Further, in Baringo County, there are three main indigenous local communities with diverse cultural backgrounds and beliefs on the land resource, hence undertake different livelihood activities. These local communities include Tugen who are crop farmers occupying mainly the hilly part (Tugen hills) with relatively high rainfall area. The llchamus who are agro-pastoralist occupying the flood plains surrounding lake Baringo, and the Pokot who are livestock keepers occupying the drier rocky area in the north-eastern part of the County. In addition, land use means different things to these local communities, and the dynamics of land use presents different opportunities and challenges for each one of them. These three main local communities employ different land use techniques which influence the dynamics of land use changes in the County as follows:

i) The Tugen Community belongs to the "Kalenjin ethnic group" and consists of crop farmers occupying mainly the county's hilly part (Tugen hills) with relatively high rainfall. They occupy four constituencies, mainly on the highlands, including Eldama Ravine, Baringo Central, Baringo North, and Mogotio Constituencies. The total land area covering the four study constituencies was $4822 \mathrm{~km}^{2}$. The area consists of 1770.4 $\mathrm{km}^{2}$ high potential, $2,069.6 \mathrm{~km}^{2}$ medium potential, $709.6 \mathrm{~km}^{2}$ low potential, and 267.2 $\mathrm{km}^{2}$ other lands (CIDP, 2018). The area supports a human population of 422,312 people, according to the 2019 population census (KNBS, 2019).

According to CIDP, 2018, land within the Tugen Community area was largely private land with title deeds, and the local communities employ modern land use practices and technologies. Based on the above statistics, most of the land falls within high potential compared with the other two constituencies i.e., Baringo South and Tiaty. The livelihood activities comprise mainly crop farming, including food crops like cereals (maize \& Beans), fruit trees and 
horticultural crops, and cash crops such as coffee, which is grown in small scale additional livelihood activity. Land resources were increasingly scarce, and building pressure resulted in land subdivisions into uneconomical units and soil and water degradation problems. These land use changes issues pose a significant challenge in sustaining the livelihood of the local communities. Land use pressure pushes Tugen local community members to encroach into water catchment and forest areas causing massive forest destruction (see appendix 2) and also force them to migrate to marginal areas seeking economic opportunities.

ii) The Pokot local community was the second largest local community in Baringo County. They belong to the "Kalenjin ethnic group." They occupy Tiaty constituency in the lowlands of Baringo County. The area covers a total land area is $4516.8 \mathrm{~km}^{2}$ consisting of $225.8 \mathrm{~km}^{2}$ high potential, $451.7 \mathrm{~km}^{2}$ medium potential, $3834.8 \mathrm{~km}^{2}$ low potential, and $4.5 \mathrm{~km}^{2}$ other land (CIDP, 2018). Livestock keeping was the primary source of livelihood. They keep cattle, sheep, goats, camels and donkeys, and derived their products. The land resource supports a human population of 171, 027 people (KNBS, 2019).

According to CIDP, 2018, approximately eighty per cent (85\%) of the land in this area fall under low potential, and it spans from West Pokot County expanding their territory into Baringo County. It borders Turkana, Samburu and encroaching into Laikipia Counties. Pokot local community moves from place to place with their livestock in search of water and pasture. The area is characterized by cycles of droughts that result in famine and acute shortages of food and water for both humans and livestock. Land use in this area revolves around the flexible movement of animals in response to sparse, erratic rainfall, short vegetation and water (Mugabe et al., 2016). The land use in the area was essentially communal under the typical arrangement. The primary source of livelihood is livestock and livestock products under an extensive pastoral lifestyle.

iii) The Ilchamus local community was the third largest local community in Baringo County. They belong to the "Maa speaking ethnic group" They are agro-pastoralists occupying the fertile flood plains surrounding, and on the islands in Lake Baringo. They keep livestock; grow crops under small-scale irrigation with subsistence fishing in the lake. They have permanent residence but occasionally move livestock from place to place, searching for pasture and water, especially during drought periods. They occupy seventy-five ( $75 \%$ ) of Baringo South constituency in the lowlands of Baringo County. The total land area is $1678 \mathrm{~km}^{2}$ broken down into $167.8 \mathrm{~km}^{2}$ of high potential, 251.7 $\mathrm{km}^{2}$ medium potential, $755.1 \mathrm{~km}^{2}$ low potential and $503.4 \mathrm{~km}^{2}$ another land (CIDP,2018).

According to CIDP,2018, most of the land was not registered and held in trust for the community by the County government of Baringo. The main challenge in the area was to harmonize competition between livestock and crop land use. The area was facing steep competition arising from rapidly expanding crop farming against shrinking livestock rearing areas. This situation was aggravated by the invasion of the poisonous tree (Prosopis Julflora), which rustle both the grazing and crop space. These problems are amplified by the rising water level of lake Baringo causing floods (Ondiege,1996). There is no organized land use system in place, the land resource is free for all; a salient feature that makes the area more 
susceptible to land grabbing characterized by inter-community land use conflicts in all directions through force and trickery by their neighboring local communities the Pokot and Tugen respectively. The land grabbing and inter-community land use conflicts in the area comes in two fronts:

a) The Pokot community invades and claims interest on Ilchamus land community land through armed raids disguised as cattle rustling. They kill, maim victims, take away livestock and sustained terror by frequent armed attacks. This forced the victims to run away from their land resource and homes to safer areas in camps as internally displaced persons (IDPs) or seek refuge elsewhere within the County and without. After that, the Pokot community quickly settled in the deserted land resource through government support. Through the help of Tiaty Constituency Development Funds (CDF), the government builds schools, hospitals, and establishes administrative units deliberately overlapping the existing boundaries and changing the names of the places. These actions occasioned intercommunity land use conflicts setting Pokot and Ilchamus as rivals. The Ilchamus community being weak politically, they are overwhelmed, displaced and forced to migrate from their ancestral land elsewhere for safety. This situation not only complicates land use but stifles livelihood options available to Ilchamus local community. In the worst-case scenario, it is almost impossible for the llchamus community to engage in basic livelihood activities and plan for future development.

b) The Tugen local community encroached into Ilchamus community land as economic immigrants and acquire land through legal manipulation techniques. The manipulation included securing grazing rights areas (Ol arabal), curving special administrative units (Endao, Arabal and Marigat locations), register group ranches (Marigat, Bartum, Barkibi A and Barkibi B), and they also set up special projects and conservancies within Ilchamus Community land. The Tugens move in and settle, then cunningly legalize their occupation through manipulation of modern laws taking advantage of their political correctness dating back to Moi's presidency and its legacy. In addition, as economic immigrants from high rainfall areas, they carry with them undesirable land use practices suited to arable areas such as cultivation of crops, and apply the same procedures on dry the lowlands. This accelerates environmental degradation on the fragile marginal area.

In summary, land use changes in Baringo County follow a mosaic system of private and communal land use approaches coupled with internal ethnic communities' rivalries. The internal local communities' rivalries, revolves around the unique cultural and sentimental attachment on land as the source of livelihood, prestige, social status, security and power. The physical and cultural survival of the specific local community depends on protecting their land and resources under the prevailing climatic and ecological conditions. These cultural attachments define the land use different local communities tend to be highly protective of their spatial justifications from potential migrants and intruders. The interaction between the diverse local communities' cultural beliefs on land use under the prevailing climatic conditions, exerts pressure on existing the land resource. As the pressure builds up, land resource becomes scarce, and competition among the local communities intensify. This scenario calls for a comprehensive study to establish the drivers of the land use change. 


\section{The Statement of the Problem}

Continuous and fatal inter-ethnic land use conflicts; causing loss of life, internal displacement, destruction of property and destitution among the local communities in Baringo county motivates this study. Baringo County is one of the 47 counties created by the constitution of Kenya 2010. It is located in the Rift Valley region between longitudes 35 30' and 36 30' East and between latitudes 0 10' South and 140'. West Pokot to the North West, Turkana to the North, Samburu to the North East, Laikipia to the East, Nakuru to the South, Kericho and Uasin-Gishu Counties to the South West, and Elgeyo-Marakwet to the West are the bordering counties. The Equator cuts across the County at the Southern part. It covers an area of $11,015.3 \mathrm{~km}^{2}$ of which 4, $435 \mathrm{Km}^{2}$ arable, 5,700 km non-arable, $715.3 \mathrm{~km}^{2}$ urban areas and $165 \mathrm{~km}^{2}$ is of surface water. The County is divided into two broad ecological zones; highlands and lowlands. The highlands cover mainly arable area, and it is largely private land with title deeds and the local communities make own decisions, employ modern land use practices and technologies with minimal land use conflicts. On the other hand, the lowlands cover nonarable which is mainly unregistered community land held in trust on behalf of the local communities by the county government of Baringo. Land use is based on collective decisions of the members which portray "free for all" land use status. This status act as a precursor for chaos, and characterized by invade and claim interest on community land, and also open ambiguity for corrupt manipulation of land ownership records. The situation has threatened lives and livelihoods, making it difficult to plan for the livelihood activities. This is happening against the backdrop of land use policy reforms including; sessional paper no 3 of 2009 on the National Land Policy, the Constitution of Kenya 2010, the Land Act, 2012, the Land Registration Act, 2012, the Community Land Act, 2016 and sessional paper no 1 of 2017 on National Land Use Policy that confers sanctity on land use. There is need to examine the dynamics of land use changes on the livelihood of the local communities in Baringo county. Therefore, this study seeks to establish the drivers of land use changes in Baringo county.

\section{The Purpose of the Study}

The study critically examined the drivers of land use changes on the livelihood of the local communities in Baringo County.

\section{Objective of the Study}

To establish the drivers of the dynamics of land use changes in Baringo County.

\section{Literature Review}

Literature review covers theoretical framework, conceptual framework, empirical literature review and empirical literature review gaps.

\section{Theoretical Framework}

Theoretically, Land is a principal factor of production, a source of life and livelihoods. It provides a means of living and a variety of uses such as agricultural, human settlement, environmental conservation, urban and industrial development purposes among others. These uses compete for space in a fixed area, hence the rising land use conflicts and degradation. Good land use system ensures optimum livelihood outcome to local communities. Any deviation from the system results to land use problems and unsustainable livelihoods. Unsustainable livelihood increases vulnerability context of local communities, thereby intensifying land use conflicts. It envisaged that sustainable livelihoods approach will 
provide important insights and a strong starting point to understanding the drivers of land use changes with respect to local communities' livelihoods focusing on the five livelihood framework's building blocks (see figure 2.1).

\section{The Sustainable Livelihoods Framework}

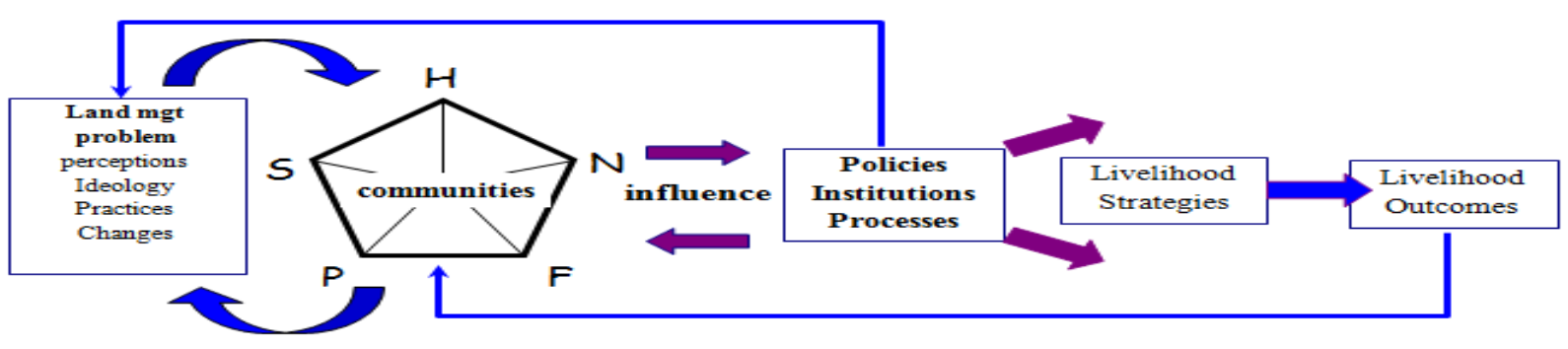

Figure 2.1: The Sustainable Livelihood Framework Source: Modified DFID sustainable livelihood framework (Carney, 1999)

The foundation of livelihood theory is the Sustainable Livelihood Framework (SLF) concept. The concept is a development intervention adopted by some major international agencies such as DFID, CARE International, UNDP and ILO, among others, to facilitate the implementation of their development programs (Solebury, 2003). The concept focuses on livelihood assets required by local communities for a means of living, enabling environment and sustainability (Scoones, 2008). The theory attempts to explain how livelihood outcomes change due to the influence of policies, institutions and processes in a logical sequence from production to output (Chambers and Conway, 1992). In this study, SLF links land use by local communities with policy organs, institutions, and processes. It is a participatory approach focusing on people's abilities and their assets. The theory has proven useful in various settings (Carney,2008), and there are many variants of the theory applied in practice depending on the purpose:

i) DFID adopted sustainable livelihood theory in administering foreign aid and focus its activities directly on improving the livelihoods of the local communities at the grassroots.

ii) Oxfam, from 1993 used a sustainable livelihood approach as a component in formulating its overall aims, improving project strategies and staff training.

iii) UNDP from 1995 used it to evaluate different types of capital (human, natural, physical, social, and financial) and examined how individuals leverage assets and cope with external sources of shocks and stress.

iv) CARE International used the theory in emergency relief administration and the design of long-term development programs holistically.

v) Rennie and Singh (1996) used the sustainable livelihoods concept in participatory research and developed a guidebook for field projects

Among the many variants of SLF, DIFID sustainable Livelihood framework with its strengths and weakness was found appropriate for this study. In a modified version to suit the objective of this study, the communities were placed at the center of the pentagon then linked to 
policies, institutions \& processes, strategies and resultant livelihood outcomes in a logical sequence as summarized in figure 2.1 ; the conceptual framework.

\section{The Conceptual Framework}

The diagram (see figure 2.1) represents the conceptual framework of the study. It has been conceptualized that the drivers of land use changes could be attributed to different perceptions, ideologies, practices and land use policy changes. This affects the livelihood assets used by local communities to derive their means of living. According to Sustainable Livelihood Framework (SLF), these livelihood assets are categorized into five types referred as capital assets which are presented in a pentagon in which local communities can build up and/or draw upon: human $(H)$, natural $(N)$, financial $(F)$, social $(S)$ and physical $(P)$.

i. Human capital $(\mathrm{H})$ represents skills, knowledge, ability to labor and good health that together, enable local communities to pursue different livelihood strategies and achieve their livelihood objectives (DFID, 2010).

ii. Natural capital $(N)$ is the term used for the natural resource stocks from which resources flow and services (e.g. nutrient cycling, erosion protection, environmental conservation, biodiversity, production assets such as forests, soil quality and water pollution) used to derive livelihoods. There is a wide variation in the resources that make up natural capital, from intangible public goods, such as the atmosphere and biodiversity, to divisible assets used directly for production (e.g. trees, land and forests).

iii. Physical capital (P) comprises the basic infrastructure and producer goods needed to support livelihoods. Infrastructure consists of changes to the physical environment that help local communities to meet their basic needs and to be more productive, whereas producer goods are the tools and equipment that local communities use to function more productively. The components of infrastructure include: affordable transport; secure shelter and buildings; adequate water supply and sanitation; clean, affordable energy; and access to information (communications).

iv. Financial capital (F) denotes the financial resources that local communities use to achieve their livelihood objectives. There are two main sources of financial capital: (1) savings, which can be held in several forms such as; cash, bank deposits or liquid assets such as livestock. Financial resources can also be obtained through credit-providing institutions and; (2) regular inflows of money: the most common types of inflows are pensions, or other transfers from the state, and remittances (DFID, 2010).

v. Social capital (S) is much debated about, notably what exactly is meant by the term 'social capital' ( Portes, 2008). In the context of the sustainable livelihoods framework as employed in this study it is taken to mean the social resources upon which local communities draw in pursuit of their livelihood objectives. These resources are developed through, and include, social networks and connectedness, membership of more formalized groups and relationships of trust, reciprocity and exchanges that facilitate co-operation, reduce transaction costs and may provide the basis for informal safety nets among the poor. (Cahn, 2006) has also argued that culture should be regarded as a separate asset that should be sustained and enhanced. The livelihoods that local communities aspire to and the strategies they choose to achieve those outcomes are both influenced by culture. However, in this study culture is treated within the social capital set. 
Furthermore, livelihood assets are influence by government policies, institutions and processes culminating to livelihood outcomes. Local communities adapt strategies to harmonizes the influence of policies, institution and processes in a bid to optimize aggregate output. Local communities' device strategies that take into account the prevailing policies, institutions, organizations and processes to shape their livelihoods. Understanding of structures and processes provides the link between the micro (individual, household and community) and the macro (regional, government, powerful private enterprise) (Cahn, 2003; DFID, 1999; Ellis, 2000; Scoones, 1998), as they effectively determine access, control and use of assets (Cahn, 2003; DFID, 2010). Understanding institutional processes also allows identification of restrictions/barriers and opportunities to sustainable livelihoods and shed light on the land use processes which underlie livelihoods sustainability (Cahn, 2003). In addition, the livelihood approach seeks to promote choice, opportunity and diversity. A livelihood strategy is a term used to denote the range and combination of activities undertaken, and choices local communities make, in order to achieve their livelihood goals (DFID, 2010). Depending on the assets the local communities have, the structures and processes that impact on them, (Cahn, 2003) would add tradition, and the land use system (communal or private land use) under which they operate, local communities theoretically choose livelihood strategies that are expected to provide best livelihood outcomes.

\section{Empirical Literature}

Empirical literature revealed that sustainable livelihood framework (SLF) appears to be most appropriate to the objectives of this study because of its specific focus on livelihoods. Livelihood analysis focuses on the identification of when, where, and how individuals, families, and communities can absorb the land use changes. These changes determine livelihood outcomes (Armitage et al., 2007). This 'Sustainable Livelihoods Approach (SLA)' has since been adopted by a range of development actors (e.g. bi-lateral and multi-lateral banks and development agencies) and provides a reasonably coherent approach for evaluating economic-social outcomes associated with local communities livelihoods.

In this study, SLA was modified to create linkage between dynamics of land use changes in agricultural practices and environmental uses of land as source of livelihood. The assets pentagon links to policies, institutions and processes under different land categories (Public land, Community land and Private land) (CoK, 2010). These land categories influence the organizational and institutional environment within which local communities draw upon assets of different types in order to implement livelihood strategies (Armitage et al., 2007; Meinzen-Dick \& Adato, 2001). In line with the conceptual framework, some empirical studies (Nyangito et al., 2002; Okoth-Ogendo, 1995; Thurston, 1987; Khamisi, 2018; Njonjo Commission report, 2002; Ndungu Commission report, 2006), indicates that the drivers of land use changes in Kenya take historical dimension associated with the policy changes in Kenya, tracing the origin from colonial era and its ripple effects running through the various political regimes after independence. This changes had great influence on the livelihood of the local communities. $n$

In this respect, Nyangito et al. (2002) investigated land laws and land use in Kenya and the implications for agricultural development. The study found out that the land use problems are chronic and associated with land use changes arising from the application of colonial statutory laws; the Indian Acquisition Act (1894), the Crown Land Ordinance (1902, 1915), the 
Crown Lands (Amendment) ordinance (1938). These laws facilitated the forceful acquisition of all productive land from local communities and alienated it for European settlers. The study also pointed out that these laws effectively gave European settlers legal mandates and enabling the environment to carry out agricultural land use activities in high rainfall areas referred to as White highlands. Nyangito pointed out that the European settlers were protected, provided with exclusive land rights, given control over labor supply through poll tax, supported in the development of resident labor (squatter system), supported to control the production of specific crops such as coffee, sisal, wheat, and dairy cattle as well as advisory services including research and agricultural extension by the colonial government particularly in the high rainfall and fertile areas referred as white highlands. Local communities were given little attention in terms of government services. Nyangito further asserts that there are a multiplicity of laws regulating land ownership and inherent inclination towards private ownership regime created disparity between arable and non-arable areas in Kenya. The non-arable areas mainly in drier parts of the county remain under communal regime causing land use conflict.

Okoth-Ogendo (1995) investigated the evolution of agrarian law and institutions in Kenya. The study found out that the colonial government applied the Native lands and trust lands Ordinance Act (1938) to drive away from the local communities from their ancestral land and their livestock from the high rainfall areas to dry and low potential rainfall referred to as Native reserves. In the reserves, local communities were restricted to subsistence crop farming such as maize and beans and livestock grazing within designated areas. OkothOgendo pointed out that land use laws were applied differently on the highlands and dry areas. This led to the Dual system of land use in Kenya. The changes encouraged high productivity farming under statutory laws in the highlands and low productivity land use practices under quasi customary law in the drier areas. This created economic disparity and a productivity gap between the highlands and drier areas. This scenario persisted throughout the colonial era and spilt over to independent Kenya. Therefore, Okoth-Ogendo asserts that a dual land use system propagated chronic divergence in land use between arable and nonarable lands which permanently distorted land use in Kenya.

Thurston's (1987) study on smallholder agriculture in colonial Kenya: the official mind and the Swynnerton Plan of 1954 found out that in the mid-1950s, the colonial government had developed a comprehensive plan to intensify land use in the local communities' areas. The Plan was drawn up in response to a crisis in land use and forms of agricultural production. The Plan stemmed from political decisions taken by the colonial government due to increasing pressures on local communities' demands and declining land productivity. The plan aimed at breaking the cycle of land productivity deterioration and alleviate local communities' livelihood by moving the greatest possible proportion of the society (approximately five (5) million people) from subsistence to commercially-oriented farming, and form a framework for future land use in Kenya. The plan delineated land use into two basic development zones; the high-potential and the semi-arid. The plan's trust focused on the high-potential lands, where four-fifths of the population was concentrated, received priority, but the plan also provided semiarid/pastoral areas. The plan was designed according to the colonial government and expert philosophy: for smallholdings of economic size, at least seven (7) to ten (10) acres, for families of six (6) to eight (8) people, to raise their income from produce sales from between five (5) and twenty (20) sterling pounds to hundred (100) sterling pounds 
a year over and above the family's basic needs (Thurston, 1987). These smallholdings were to be consolidated in the fragmented areas, surveyed, registered, and developed over a period of fifteen (15) years as freehold farms with indefeasible titles. The study concluded that the Swynnerton plan became the key driver of the land use in Kenya and a blueprint land use policy during the colonial regime and its legacy spillover to independent Kenya. The primary plan failure of the plan was the neglect and marginalization of drier areas in the country, which led to imbalances in development between different regions. The plan also created landless class and loss of communal grazing areas, among others. The plan reinforced the concept of dualism in land use changes in Kenya, pitting the rich European settlers and local communities, while in the independent government of Kenya, dualism in land use changes worked against political connected elites with the local communities.

\section{Empirical Literature Review Gaps}

In summary, the empirical literature review reveals that dual land use system gap is key the driver of land use changes in Baringo County. This problem originated from colonial land use policy and its application on arable lands and non-arable lands. Historically, arable areas which use to be occupied by white European farmers applied modern technologies developed in Europe designed for well-developed infrastructure. These technologies were applied in tropical environment characterized by poor infrastructural development. This poses application and incompatible challenges in relation to ecological conditions. On the other hand, the non-arable areas continued employing customary system under restricted grazing and movement. The system was characterized by skewed resource allocation in terms of government's budgetary allocation hence regional development disparities. Further, the Swynnerton plan of 1954; the blue print land use policy in Kenya during the colonial era was bias toward arable areas in terms of budgetary allocation to non-arable areas. The same scenario persisted even after independence and trends to be irreversible causing perpetual land use conflicts. Empirical evidence show that land use policies favor registered private land compared with unregistered community land.

\section{Methodology}

The study methodology covers the study design, basic information about the study area, methods and data collection as well as analytical framework.

\section{The Study Design}

The study design entailed comprehensive desk review of existing literature on land use policies in Kenya, and Baringo county. It focused on diverse aspects of land use with respect to climatic and ecological characteristics. The design was adopted because of the known characteristics of the representative constituencies to capture in-depth details as follows:

i) Tiaty constituency compromise of East Pokot and Tiaty East. The constituency was purposively picked because of the ASAL climatic conditions, traditional beliefs, communal land use, the practice of pastoralism as a source of livelihood and increasing land use conflicts. Changing livelihood; several pastoralist households are increasingly dropping out of pastoralism. They are settling down and establishing permanent residence, then start engaging in crops production economic activities.

ii) Eldama Ravine constituency was purposively selected due to the high rainfall highland climatic conditions, intensive land use associated with massive 
subdivision of land into uneconomic units, widespread soil and water degradation, characterized encroachment into forest and movement of the population from highland into marginal areas seeking economic opportunities, use modern technologies and land is privately owned with title deeds.

iii) Baringo South was purposively selected because of its marginal climatic conditions, land use is communal, receive an influx of economic immigrants from highlands as well as those from ASAL, it was seen as the center of land use conflicts, a clash area of cultural beliefs.

iv) Baringo North was purposively selected because it combines highland and lowlands climatic conditions, a mixture of private and communal land use practices.

\section{The Study Area}

The study covered the entire Baringo County. The county is one of the 47 counties in Kenya. Located between longitudes 35 30' and 36 30' East and between latitudes 0 10' South and 1 $40^{\prime}$. The Equator cuts across the county at the southern part. It covers an area of 11,015.3 sq $\mathrm{km}$ of which $165 \mathrm{sq} \mathrm{km}$ is of surface water. The county is divided into two ecological zones, highlands and lowlands, with a transitional zone (marginal area) between the two zones. In the highlands, crop production was the main livelihood activity. The dominant crops grown on the highlands include cereals (maize, sorghum and finger millet), legumes (beans, green grams and cowpeas), roots and tubers (Irish potatoes, sweet potatoes and cassava) and nuts and oils (groundnuts, macadamia nuts, coffee and cotton). The Lowlands constitute both arid and marginal areas. The marginal area constitutes approximately $25 \%$ of the total land area and is seen as the convergence of land use changes. The arid lands constitute largest land area in the county. The arid area is characterized by sparse, erratic rainfall and scarce water resources. The area is prone to land use conflicts.

\section{Methods and Data Collection}

The study reviewed the existing literature in books, internet and repositories of national government, national archives, relevant institutions and County governments. The study also employed visits and consultation methods to gather information from the relevant departments and institutions at different levels. This information was necessary to clarify issues, capture current land use trends and sought additional insights.

\section{Data Sources}

At the national level, in addition to the existing literature, the researcher visited and consulted informants in the relevant departments in the Ministry of Lands and Physical Planning, National Land Commission (NLC), private experts, Civil Society Organizations and National Archives. Specifically, the researcher interviewed Senior Officers in the land registry (Central \& Nairobi), Physical Planning, Land Adjudication \& Settlement, Land Administration, Land Valuation, Survey Plans Records Office (SPRO), Survey of Kenya and National Titling Centre under the Ministry of Lands and Physical Planning. The researcher also visited and consulted the relevant Officers at Kenya National Archives in Nairobi. On the same light, the researcher further sought views from representatives of various professionals' bodies and government agencies involved in the land resource management and administration. These bodies and agencies included Institution of Surveyors of Kenya (ISK), Kenya Bankers Association (KBA), Kenya Private Sector Alliance (KEPSA), Law Society of Kenya (LSK), Architectural Association 
of Kenya (AAK), Land Development and Governance Institute (LDGI), Kenya Property Development Association (KPDA), Town and County Planners Association of Kenya (TCPAK) and Kenya Institute of Planners (KIP) on land use issues in the Kenya. These respondents covered the entire land use processes from physical planning, surveying, land administration, valuation and registration. In addition, the researcher also interviewed some strategic Civil Society Organizations (CSOs) who play a fundamental role in advocating and safeguarding various public and local communities' interests in matters related to government policy on land use.

\section{Data Collection at County Level}

Data collection was done in two levels; at the neighboring Counties and Baringo County.

\section{i) Data collection at Counties neighboring Baringo County}

The researcher visited the eight (8) neighboring Counties of Elgeyo-Marakwet, Kericho, Nakuru, Samburu, Turkana, Uasin Gishu, West Pokot and Laikipia . In these neighboring Counties, the researcher personally interviewed the land sector officials including CEC in charge of lands, the County Physical Planner, the County Surveyor, the County Legal Officer and Members of County Assembly (MCA). The section criteria based on the assumption that respondents had extensive knowledge and practical experience on the land use changes in their respective Counties. Specifically, the MCAs were selected as representatives of the local communities at the Ward level hence their views were considered to reflect the local communities' perspectives under different land use regimes.

\section{ii) Data collection in Baringo County}

In Baringo County, in-depth data collection was carried out at County headquarters, in four (4) constituencies and Sixteen (16) Wards (i.e. 4 wards per constituencies) and three hundred twenty (320) Household heads (i.e. 20 respondents in the villages per ward). The data obtained was deemed satisfactory to elicit the diverse local communities' land use aspects reflecting the entire County. At County headquarter, the researcher interviewed the land sector officials including County Executive Committee (CEC) member in charge of lands, the County Physical Planner, the County Surveyor, County Legal Officer and Members of County Assembly (MCAs). At Sub-County level, representative samples of key informants were interviewed at random in the selected Constituencies namely Baringo South, Baringo North, Tiaty and Eldama Ravine. These constituencies were purposively selected on the basis of their climatic and ecological characteristics. The information was considered adequate in representing the actual situation on the ground.

\section{Analytical Framework}

The analysis was qualitative focusing on land use policies in Kenya, linking the analysis to Baringo County as a devolved unit. The data obtained from the various sources including Ministry of Lands and Physical Planning, National archives, past studies in academic journals, internet and books, as well as opinions heard and researcher's own observations were consolidated and descriptively analyzed. 


\section{Study Findings}

The study findings follow historical evolution of land use changes in Kenya focusing on divergence between land use practices in arable highland climatic conditions under registered private land tenure and non- arable ASAL climatic conditions under unregistered communal land tenure. The findings were presented in three sections; section one covered the period from 1895 to 1963, section two covered the period between 1963 to 2010 and section three covered the Period 2010 to 2020 . The study findings were summarized per section as follows:

\section{Section One; The Colonial Era (1895 to 1963)}

The study found out that the drivers of land use changes management in Baringo County was historical emanating from colonial era including change of land use policy from communal to individual tenure, dual application of land use policies and laws, the mindset of policy makers and technocrats and intervention approaches. First, the colonial regime changed the land use policy from customary arrangement; where land resource was managed collective by members of ethnic community to individual land resource management; basically, to suit the colonial masters' commercial interests. Accordingly, during the pre-colonial era, land resource was managed by unwritten law and rules passed down from generation to generations through story telling. The Chiefs working with a team of community elders allocate rights to access and use of land to individuals or groups. Individual ownership and rights to sale land never existed. Land was perceived as non-tradable assets. These arrangements then worked well for the local communities' members and non-members livelihoods (Wanyonyi, Nyandimo and Kariuki, 2015). During the colonial since 1920, when Kenya was declared British colony, all land in the country converted to crown land (Wakoko, 2014). Europeans settlers were allocated best arable land referred as "white highlands". The local communities were displaced and driven to the native reserve at the lower Rift valley including Baringo County. These areas were characterized by low rainfall, poor soil and lack of enough pasture (Wanyonyi et.al., 2015). Those who did not find place to settle become squatters and were enslaved to labour without pay in the European settlers' farms (TJRC,2013). The new policiesat encouraged large scale production and individual land use decisions. Beside land use policies, the colonial government associated the centrality of land resource in the governance structure of the British Colony including Baringo County. The colonial regime viewed land resource as a critical factor of production and perceived it as the source political power by the government. The perception influenced land use policies, legislation and practice. The change had far reached effects and greatly influenced the local communities' livelihood practices during and after colonial regime. The changes caused displacement of the local communities and rendered them tenants on the crown land, broke the cycle of their shifting cultivation production system, restricted movement of their livestock keeping system hence breaking the cycle of dry and wet season grazing. This distorted local communities' production processes. The local communities were confined in the reserves which denied them opportunities for technological adaptation and limiting their livelihood options.

Second, the study found out that colonial regime adopted a dual land use system of land use which was aimed at providing an enabling environment for production activities and at the same time facilitates governance of the Country. The regime was bias toward supporting productions processes for European settlers and neglected the local communities. The colonial government allocated resource for extension, research development and export commodities markets development to cater for European settlers needs and deprives the 
local communities. Consequently, this approach spurred long term land resource management problems, and in some cases irreversible negative effects on the local communities' livelihood. The negative effects included displacement of local from fertile arable areas, accelerated soil erosion and environmental degradation among others. In addition, the study found out that colonial government held a strong perception that customary land resource management system was backward and regarded it as production system without returns. In essence, the colonial government promoted two parallel land resource management systems which continued in a modified version even after independence. The study found out that the application of this dual land use had far reaching and sometimes irreversible effects on the local communities' livelihood practices during and after colonial regime.

Third, the study established that the mind set of policy makers and technocrats influenced the design of policies and strategies adopted by colonial government. The design deliberately intended to cause disparity in order to create demand for labour required in European settlers' farms, and at same time weaken the social and economic systems of the local communities. Technically, the discrepancy rendered local communities' workers of the European settlers thereby increased land productivity in the European farms while undermining production activities in the local communities' areas. European experts' and policy makers hold the ideology that exclusive access to land and an enclosed land holding with a perimeter fence around it, provides opportunities to plan and produced large quantities for commercial purposes. This perspective influenced greatly land use policies in the local communities' areas during colonial times. It saw land productivity capacity declining and growing misery over the years especially in the local communities' areas. The conflicts in ideologies where by European experts pursue on technical solutions, while the local communities pursued welfare aspects. This regime disorganized customary land use creating disequilibrium in the production system and distorted livelihood options for the local communities generally in Kenya as British colony including Baringo County.

Four, the study found out that colonial government appointed commissions and several study teams to investigate and recommend best land use policies to alleviate the situation. These included; the Carter Land Commission of (1932-1933) the defined the European highlands and local communities' areas, the Maher study (1935), on soil conditions in Kamasia (now referred as Tugen hills covering Eldama Ravine \& North Baringo Constituencies), Njemps (now referred as Ilchamus area covering Baringo South Constituency), East Suk (now referred as East Pokot covering Tiaty Constituency). The study reported that an ecological crisis was approaching, the multi-skills team study (1945) on general conditions affecting land use. The study recommended radical reforms to be undertaken on new agricultural methods and drought resistant crops and restore communal feeling (by introducing cooperative or group farming, reviving the clan system, renew interest in the mixed smallholdings farmed on a rotational balance, farm planning which started with the livestock-carrying capacity, the concept of ecological zones in land use planning and development of the Swynnerton plan of 1954). The Swynnerton plan was designed according to colonial government and expert philosophy; for smallholdings of an economic size, at least 7 to 10 acres, for families of 6 to 8 people. To raise local communities' income from produce sales from between 5 and 20 sterling pounds to100 sterling pounds a year over and above the family's basic needs. These smallholdings were to be consolidated in the fragmented areas, surveyed, registered and 
developed over a period of fifteen (15) years as freehold farms with indefeasible titles. This plan became the blue print land use policy in Kenya during the colonial region and its legacy spillover to the independent Kenya and Baringo County by extension

\section{Section Two; At Independence Onwards (1963 to 2010)}

The study found out that since 1963, when Kenya gained its independence, land use was placed under the executive mandate of the presidency. The presidency was tasked to initiate resettlement programme. The settlement schemes were massively affected by corruption from the presidency, local politicians, elites and businessmen. Illegal allocation and land grabbing were rampant; officials conspire to destroy transactions evidence (Khamisi, 2018). The elite took advantage of situation and inherited European farms and continued managing them under the principles laid down in the Swynnerton plan i.e statutory laws, while poor local communities especially in the arid and semi-arid lands (ASALs) continued managing land under customary arrangement. The scenario created disparities in application of policies, thereby influencing production activities, human settlement and conservation of environment in different parts of the County. These disparities were compounded by the mindset carried over from colonial government strategies by the ruling class and elites after independence. The philosophy that customary land use system was as an impediment to large scale production and stumbling block to private commercial investment stacked in policy decisions. This mindset strongly held that customary land resource was a production system without returns and lacked direct interaction with the rest of the world hence limiting domestic and foreign trade transactions.

Furthermore, the study found out that this argument led to development of skewed land use policies and intervention strategies; where European settlers were properly supported in terms of government budgetary allocation and other requisite services such as research, extension and access to foreign markets for their products, but the local communities were neglected, pushed and restricted to drier parts of the County. This disparity in application of policies and government interventions limited production processes and opportunities for technological adoption by the local communities. This stifled livelihood activities leading to low production and perpetual resource conflicts among the local communities especially in the drier parts of the County. This scenario was made worse by the fact that over eighty per cent ( $80 \%$ ) of total land area in Baringo County was under customary management, while the rest was under statutory law (Baringo County CIDP, 2018-2022).

Moreover, at independence in 1963, and subsequent years up to 2010, Kenya government redistributed land, settled and resettled local communities in areas previously occupied by European settlers. The study found out that the arrangement was bias toward helping some ethnic groups while marginalizing the original land owners especially in arable areas. Surprisingly the independent government retained and reinforced colonial land resource management policies, and adopted the legal framework that categorized land into Government, Private and Trust land. These categories were under different land use regimes: The Government land, formerly Crown land, was land owned by the Government for her own purposes and which included unused or unalienated Government land reserved for future use or could be availed for various general public uses. This land was administered under the Government Lands Act (GLA), Cap 280. Trust land which comprised of land held under Trusteeship by various County Councils on behalf of the local communities. The local 
communities used the land under their customary laws and rights but had no registered interests on it. Land under this category was managed and administered under the Trust Land Act, Cap 288. This category of land has been diminishing following application of reforms through adjudication and registration programmes. The private land was land owned by individuals, groups or companies in freehold or leasehold tenure after registration and issue of title following allocation from government land, or derived from Trust land after implementation of consolidation and/or adjudication and resettlement programs. Freehold is the largest quantum of rights that a person can hold in Kenya and gives the holder absolute ownership of the land. A freehold title deed usually has no restrictions on the use or occupation though there are some conditional freeholds that restrict use to for instance agricultural or ranching purposes only. Leasehold is an interest on land for a term of years and may be granted by a freehold rights holder usually subject to the payment of a fee or rent and also subject to some conditions for instance on development and use. Leases were granted by Government over Government land, the County Councils over Trust land and by individuals or organizations over their freehold land.

The study found out that land tenure system was closely associated with land use conflicts. This situation among other land related issues sparked numerous calls for land reforms. These calls were driven by urge to provide solutions and review outdated laws based on the provisions of the Swynnerton plan 1954 and the old Constitution of Kenya. Moreover, the study found out that the structural changes in terms of technology advancement made many provisions of the plan redundant. However, the study found out that land reform agenda culminated to formulation of Nation Land Policy (2009) which aimed to replace the Swynnerton Plan. The provisions in the National land policy were entrenched into the Constitution of Kenya (2010). This was perceived by many to be the new dawn to solving the land resource management problems in Kenya and by extension Baringo County. Indeed, land reform agenda introduce radical changes on land use reforms from 2010 onwards which included, the implementation of the provisions in the National Land Policy that aimed to addressing land resource management problems and provide for sustainable growth, investment and the reduction of poverty. The policy as stipulated in Article 60 of the Constitution of Kenya 2010 states that land resource in Kenya shall be held, used and managed in a manner that is equitable, efficient, productive and sustainable and the policy also outlined land use management issues; land administration issues; land issues requiring special intervention and also proposes an implementation framework.

In this respect, study found out that the policy principles made proposals on tenure types and terms, legislation and an institutional framework that informed various provisions of the 2010 Constitution. These included: a) the classification of land into public, community and private categories; b) the limiting of land leases to 99 years; c) the consolidation of substantive land laws into one Land Act; d) the consolidation of the various land registration laws into one piece of legislation to govern registration of title to land; e) the non-discrimination of women and youth; f) the devolution of land governance; and g) the establishment of a national land commission to manage public land. In this respect, the study also found out that that land reform agenda proposed changes in the land resource management regimes with provisions for protection of land and environment. The reforms were guided by key principles geared to improve the land resource management in Kenya. These principles include; equitable access to land, security of land rights, sustainable and productive management of land, transparent 
and cost effective management of land, sound conservation and protection of ecologically sensitive areas, elimination of gender discrimination in law, customs and practices related to land and property in land and encourages communities to settle land disputes through recognized local community initiatives.

\section{Section Three; Land Reform (2010 to 2020)}

Indeed, the study also established that the Constitution of Kenya (2010) in agreement with the provision of National Land Policy (2009) classified land in Kenya into public, community and private under different land resource management systems. It further gave the guiding principles on acquisition, use and disposal of land rights include equal recognition and enforcement of land rights arising from all forms of land resource management systems; nondiscrimination in ownership of, and access to land under all land resource management systems; the protection and promotion of the multiple values of land and the development of fiscal incentives to encourage the efficient utilization of land. Rights of ownership reflect the quantum of rights that different management systems confer on individuals, groups of individuals or other entities. A land owner enjoys the right to use, the right to dispose of and the right to exclude others from his land. These categories in Articles 62 (Public Land), 63 (Community Land) and 64 (Private Land) in the Constitution as elaborated as follows: Public land; the entire range of what constitutes public land is found in Article 62. It include land that was un-alienated government land at the effective date; land lawfully held, used or occupied by state organs; all minerals and mineral oils government, forests $\operatorname{gr}$ (not community forests); rivers, lakes and other water bodies, roads and thoroughfares; the territorial sea; the continental shelf; land between high and low water marks and also any land not classified as private or community land. Public land in Kenya is approximately $13 \%$ of Kenya's land size (BOA, 2018). These lands have implications on the livelihood of the local communities in terms of space for agricultural research on various crop varieties like coffee, tea, potato, maize, cotton and rice, among others. Other state farms are committed to dairy farming and ranching, mainly for purposes of breeding stock and semen production for local farmers. Unfortunately, some of this land had been irregularly allocated, diminishing the total size of public land.

Community land; provided for under Article 63, is vested in and held by Communities identified on the basis of ethnicity, culture or similar community of interest. The full range of this land is listed in the Constitution. It includes land lawfully registered in the name of group representatives under the provisions of any law; land lawfully transferred to a specific community by any process of law and any land that is declared to be community land by an Act of Parliament. The Constitution further provides that any unregistered community land shall be held in trust by county governments on behalf of the communities for which it is held and that community land shall not be disposed of except in terms of legislation specifying the nature and extents of the rights of the members of each community individually or collectively. It should be noted that since was enacted in September 2016 to date it has not been implemented. The Act provides for the recognition, protection and registration of community land rights. But this law, which became effective on $21^{\text {st }}$ September 2016, is yet to be applied because the institutional organs not established and the process of identification, mapping and registration has not yet started. Community land is approximately $68 \%$ of Kenya's land size (BOA, 2018) including the entire Northern parts of Kenya (Turkana, Mandera, Marsabit, Wajir, Garissa), Samburu and Baringo among other ASAL Counties. 
Moreover, the study observed that the Community Land Act 2016 created ambiguity in administration and access to community land hence aggravating Land use conflicts further. This scenario coupled with mounting competing claims on the land resource such as the demand for space the growing population both internally (local population) and externally (migrating communities seeking economic opportunities), deteriorating environmental quality, increasing agricultural activities, emerging underground activities including mining of minerals, oil exploration, geothermal power generation, and increasing intensity of natural calamities such as drought and floods escalated land use conflicts in the community land.

Private land; Article 64 defines private land to consist of registered land held by any person under any freehold or leasehold tenure and any other land declared as private land under any Act of Parliament. The substantive law governing private land in Kenya is currently embodied in the Land Act, 2012. Private land in Kenya is approximately $19 \%$ of Kenya's land size (BOA, 2018). The $19 \%$ of Kenya's land under private land holdings practically supports most of Kenya's farm economy. Early efforts by the colonial government were focused on developing an agricultural economy. The lands allocated to settlers for this purpose was usually on the 'White Highlands' which included most of Kenya's high potential land. This is therefore where most of farm and dairy production was focused, with few exceptions that focused on ranching in some of the medium potential zones of the Rift Valley, Eastern regions of Kenya. It is some of these farms that later changed hands to local ownership, with some getting purchased, subdivided and allocated to indigenous Kenyans through government-driven resettlement and settlement schemes. The rest of this private land is in the former 'African Native Reserves' which were subjected to consolidation and adjudication in the 1950s and 1960s, producing many small holder farms for settlement and small-scale agriculture by local people.

The study noted that the land reforms entailed enactment of several laws governing land use in Kenya which were intended to put into effect the provisions in the constitution:

i. The Environment and Land Court Act, 2011 which provides a legal framework for determining disputes relating to the environment and the use and occupation of, and title to, land. It establishes a court with similar status to the High Court for the purpose.

ii. The Land Act, 2012 provides a framework for the revision, consolidation and rationalization of Kenya's previous land laws and for the sustainable management of land and land-based resources. This Act also contains substantive provisions for the rights, obligations, transactions and management of public and private land and repeals the previous Way leaves Act (Cap 292) and the Land Acquisition Act (Cap 295). It supports freehold, leasehold, customary and other forms of partial interest that may be defined under the Act. It also provides for the process of compulsory acquisition and compensation of private or community land.

iii. The Land Registration Act, 2012 provides framework for the registration of title to land in Kenya and gives effects to the principle and objects of devolved government in land resource management. It repeals all previous laws that had land registration and conveyance provisions. This law, however, contained provisions that required one to obtain spousal consent before transacting on matrimonial property. This provision was struck off in the Land Registration Act through the Land Laws (Amendment) Act of 2016. The requirement that any dealing on matrimonial property must be accompanied by the consent to 
the spouse(s) is now carried in the Matrimonial Property Act. The Land Registration Act also establishes County land registries and a community land register.

iv. The National Land Commission Act, 2012 provides for the powers and functions of the Land Commission and gives effect to the principles of devolved land government in land administration and management. The Commission manages public land on behalf of the national and county governments.

v. The Community Land Act, 2016 provides for the recognition, registration and protection of community land and creates governance organs to help in the management and protection of community land. This law will be applicable to over two thirds of Kenya, where land remains unregistered and under customary arrangements. It repealed the Land (Group Representatives) Act (Cap 287) and the Trust Lands Act (Cap 288).

However, the study established that audits were conducted, and reports on the enacted laws revealed inconsistencies. The recommendations led to The Land Laws (Amendment) Act, 2016 enacted to amend the 2012 land Act, Land Registration Act and National Land Commission Act to align them with the Constitution. It also contains amendments to the Land Act providing for the regulation of land sizes of private land holdings, and another providing for a process to evict unlawful occupiers from public, private and community land. Amendments to the National Land Commission Act, providing for the investigation of historical land injustices and recommendations for redress by the Land Commission, are contained in this law. This law also clarifies the roles of the Ministry responsible for Lands, and that of the National Land Commission, to avoid conflicts over mandate. Good quality data and statistics are essential inputs to inform policy making and decision taking.

\section{Conclusions and Recommendation Conclusions}

The study concluded the key drivers of land use changes in Baringo county is mainly driven by the dual land use policy associated with land tenure security. The drivers revolve around dynamics of registered private land in the highlands and unregistered land in the lowlands. There are two key salient features that emerged to be the main drivers of the dynamics of land use changes in Baringo County. The dynamics were more pronounced in the lowlands which is largely dry areas within the unregistered community land. This area is characterized by invaded and claim land rights and strategic encroachment approaches of land use. These features demonstrate unscrupulous seizure of land resources from one ethnic community by others, occasioning frequent and fatal inter-ethnic land use conflicts. The situation was chronic with consequences that led to forced eviction, continued deterioration of agricultural land productivity, increasing environmental degradation, and the emergence of different land use patterns, and widespread poverty prevalent in the area. This makes the current land reform initiatives redundant, and land resources were primarily used and managed according to the local communities' customary arrangements. The study concluded that land resource management were based on wrong policy orientation. The policies were not responsive to local communities' aspirations and needs, resulting to unsustainable livelihood and wide spread poverty particular in the drier areas of the County. 


\section{Theoretical Recommendations}

The study results have added to the existing knowledge on the issues surrounding communal land and other dynamics that influence the implementation of land reforms in the country. The results support the applications of the sustainable livelihood framework (SLF) theory and shed light on the understanding and its relevance in land use studies. The study also recommends that other theories supporting the understanding of the land use and its dynamics should beapplied by other researchers on more extensive area other than one County. This will shed more light on the understanding of the underlying factors influencing land use changes and associated dynamics. There is a need for government to sensitize communities about land reforms. This will create awareness and facilitate implementation of land use policies thereby improving the livelihood of the communities. The study noted a high level of destitution among the local communities in areas affected by land use conflicts, causing unstable and uncertain livelihoods. Communities need to be sensitized to use current technologies and adopt modern methodologies that can help in improving the land utilization and cope with the global trends. These will enhance the level of livelihood among the households.

\section{Policy Recommendations}

The study recommends implementation of Community Land Act, 2016. The Act has provisions for recognition of local communities, protection and registration of their land rights. Registration will enhance land tenure security and resolve land use conflicts. There is a need to change the mindset of the policymakers and experts to be responsive and relevant to local communities' livelihoods. Land use policies should avoid dual land use system, and focus on local communities priorities, capabilities, experiential Knowledge and basic livelihood activities in their locality such as Livestock and crop production as conceptualized by the local communities. For example, suppose the policy goal is to enhance livestock productivity as the critical driver of livelihood of land use in dry areas. In that case, this could be attained by enhancing water resources and feeds, enhancing animal disease and pest control, smoothening Land use measures, improving the management of the environment and natural resources, improvement of Infrastructure, promoting formal and informal Education, enhancing Human and social development and breeding services. These activities should be embodied in the policy. The study recommends complete overhaul of the policy orientation driven by local communities' experiential knowledge.

\section{Reference}

Ahmed, A. G. M. (2001). Livelihood and resource competition, Sudan. Mohamed Salih, Dietz and Mohamed Ahmed (eds.) African Pastoralism: Conflicts, Institutions and Government. Pluto Press, London, 172-193.

Ahmed, I., \& Lipton, M. (1997), 'Impact of structural adjustment on sustainable rural livelihoods: a review of the literature, IDS Working Paper 62, Brighton: IDS.

Alimaev, I. I., \& Behnke Jr, R. H. (2008). Ideology, land tenure and livestock mobility in Kazakhstan. In Fragmentation in Semi-Arid and Arid Landscapes (pp. 151-178). Springer, Dordrecht.

Anand, P. (1993). Foundations of rational choice under risk. Journal of Environmental Economics and Management

Anderson, D., \& Lochery, E. (2008). "Violence and Exodus in Kenya's Rift Valley, 2008: Predictable and Preventable? Journal of Eastern African studies. 
Andre, C., \& Platteau, J. P. (1998). "Land relations under unbearable stress: Rwanda caught in the Malthusian trap," Journal of Economic Behavior and Organization, vol. 34 (1): 147.

Armitage, D., Berkes, F., \& Doubleday, N. (Eds.). (2007). Adaptive Co-Management: Collaboration, Learning, and Multi-level Governance. Vancouver: University of British Columbia Press

Atwood, D. A. (1991). "Land registration in Africa: The impact on agricultural production," World Development, vol. 18 (5): 659-71.

Aspinall, J., and Hill, M. J. (2008). Land use change: Science Policy and Management, New York; CRC Press

Baulch, R. (1996), 'Neglected trade-offs in poverty measurement', IDS Bulletin 27: 36-43

Behnassi, M., \& Yaya, S. (2011). Land resource governance from a sustainability and rural development perspective. In Sustainable agricultural development (pp. 3-23). Springer, Dordrecht.

Ben-Akiva, M. E., \& Lerman, S. R. (1985). Discrete choice analysis: theory and application to travel Demand- MIT press.

Bennet, C. N. (1973). Research Methods in Universities. Route/edge. London.

Berkes, F., George, P. J., \& Preston, R. J. (1991). The evolution of theory and practice of the joint administration of living resources. Alternatives, 2(18), 12-18

Bezemer, D. J., Lerman, Z. (2002). Rural Livelihoods in Armenia. The Centre for Agricultural Economic Research, the Department of Agricultural Economics and Management Discussion Paper No. 4.03.

Bloom, L. H. (1985). Psychological testing and assessment. Boston: Mc Graw Hill

Bloomberg, M. (2015). Erosion susceptibility classification and analysis of erosion risks for plantation forestry-response to Marden et al.

Bloomberg, M., Morgenroth, J., Rosser, B. J., Page, M. J., Harrison, D., \& Jones, H. (2012). 5 Erosion, land use, erosion control, \& land tenure in the Waiapu catchment. Waiapu River Catchment Study, 173.

Boli, R. (2005). Livelihood assets of rural Kenyans. Senior Seminar in International Development Studies (IDS) Final Paper. Retrieved 13/10/2012 from http://schant.socialdev.net/data/FAO/IDS_2006_boli.pdf

Borg, W. R., \& Gall, M. D. (1989). Ed Research. An introduction (4th Ed). New York.

Boserup, E. (1965). The Conditions of Agricultural Growth: The Economics of Agrarian Change under Population Pressure, London: Earthscan Publications.

Bruce, J. W. (1986). Land tenure issues in project design and strategies for agricultural development in sub-Saharan Africa (No. 1804-2019-3070).

Cahn, M. (2003). Sustainable livelihoods approach: Concept and practice. In D. Story, J. Overton \& B. Nowak (Eds.), Contesting development: Pathways to better practice. Proceedings of the third biennial conference (pp. 284-288). Aotearoa/New Zealand Development Studies Network (Dev-Net)

Cahn, M. (2006). Sustainable rural livelihoods, micro-enterprises and culture in the Pacific Islands: Case studies from Samoa. Unpublished doctoral thesis, Massey University, Palmerston North, New Zealand

Cahn, M. L., Conner, M. M., Schmitz, O. J., Stephenson, T. R., Wehausen, J. D., \& Johnson, H. E. (2011). Disease, population viability, and recovery of endangered Sierra Nevada bighorn sheep. The Journal of Wildlife Management, 75(8), 1753-1766. 
Carney, D., Drinkwater, M., Rusinow, T., Neefjes, K., Wanmali, S., \& Singh, N. (1999). Livelihoods approach compared: A brief comparison of the livelihoods approaches of the UK Department for International Development (DFID), CARE, Oxfam and the United Nations Development Programme (UNDP), November 1999. London: Department for International Development.

Carney, D. (1998). Implementing the sustainable rural livelihoods approach. Paper presented to the DfID Natural Resource Advisers' Conference. London: Department for International Development.

Carney, D. (1999). Livelihood approaches compared. London: DFID.

Carney, D. (1999). Sustainable Livelihoods: What Contributions Can We Make? London: Department of International Development.

Carswell, G. (1997), 'Agricultural intensification and sustainable rural livelihoods: a think piece', IDS Working Paper 64, Brighton: IDS.

Chakrabartty, S. N. (2018). Better composite environmental performance index. Interdisciplinary Environmental Review, 19(2), 139-152.

Chambers, R., \& Conway, G. (1992). Sustainable rural livelihoods: Practical concepts for the 21st century. Brighton: Institute of Development Studies, University of Sussex. (IDS discussion paper; no. 296.).

Chambers, R. (1983). Rural Development: Putting the Last First. : Harlow: Longman Scientific and Technical, Essex.

Chambers, R. (1999). Relaxed and participatory appraisal: Notes on practical approaches and methods. Brighton: Institute of Development Studies, University of Sussex.

Cheche, K. (1982). Independent Kenya. Nairobi: Zed Press.

Cherni, J. A., Hill, Y. (2001). Hill energy and policy providing for sustainable rural livelihoods in remote locations: the case of Cuba J. Geoforum 40 (4).

Cobb, C. W., \& Douglas, P. H. (1928). Theory of production American Economic Review.

Constitution of Kenya. (2010) The Constitution of Kenya (2010). Retrieved from.

Cotula, L., Toulmin, C., and Hesse, C. (2004). Land Tenure and Administration in Africa: Lessons of Experience and Emerging Issues, International Institute for Environment and Development, London.

Cox, M., Arnold, G., \& Tomás, V. S. (2010). A review of the design principles for communitybased natural resources management Ecology and Society 15(4), 38.

Crosbie, W. (2005). The Essential Research Skills. Suva, Fiji: Amokura Publications.

Daudeline, J. 2002. "Land as a source of conflict and in the post-conflict settlement," World Bank Regional Workshop on Land Issues in Africa and the Middle East, April 29May 2, 2002, Kampala, Uganda.

Davis, C. K. (1997). How to design and evaluate research. New York: Mc Graw Hill

Davies, S. (1996). Adaptable Livelihoods. Coping with Food Insecurity in the Malian

Davis, B., Winters, P., Carletto, G., Covarrubias, K., Quiñones, E. J., Zezza, A., ... \& DiGiuseppe, S. (2010). A cross-country comparison of rural income-generating activities. World Development, 38(1), 48-63.

Debertin, D.L . (1986). Agricultural Production Economics, Collier Mac Millan, Canada.

Deininger, K. (2003). Land Policies for Growth and Poverty Reduction: A World Bank Policy Research Report, Oxford and New York: World Bank and Oxford University Press.

Deininger, K., \& Castagnini, R. (2005). "Incidence and impact of land conflict in Uganda," Journal of Economic Behavior and Organization, forthcoming. 
Desai, K. (2002). Land Reforms through People's Movements. Land Reforms in India: Issues of Equity in Rural Madhya Pradesh.

Dharmasiri, L. M. (2009). Applicability of Cobb-Douglas production function in measuring the spatial variation of agricultural productivity in Sri Lanka, University of Peradeniya Press.

DFID. (1999) Department for International Development). Sustainable livelihoods guidance sheets. Available from the livelihoods learning platform www.livelihoods.org.

DFID. (2000). (Department for International Development) Sustainable Rural Livelihoods Guidance Sheet, London, UK.

DFID. (2001). Sustainable Livelihoods Guidance Sheets: Retrieved May 12, 2006, from http:/www.livelihoods.org/info/info_guidancesheets.html

Dorward, A. (2009). Integrating contested aspirations processes and policy: development as hanging in, stepping up as stepping out. Journal development policy revision 27 (2) 131146

Dow, J. K., \& Endersby, J. W. (2003). Multinomial Probit and Multinomial Logit: a comparison of Choice Models for Voting research

Drimane, S. (2002). "HIV/AIDS and Land: Case Studies from Kenya, Lesotho, and South Africa," report, Human Science Research Council, Pretoria, South Africa.

Ellis, F. (2000). Rural Livelihoods and Diversity in Developing Countries. New York: Oxford University Press.

Ellis, F., Bahiigwa, G. (2003). Livelihood and rural poverty reduction in Uganda J. World Deve. $31(6), 997-1013$.

Farrington, J., Ramasut, T., Walker, J. (2002). Sustainable Livelihoods Approaches in Urban Areas: General Lessons, with Illustrations from Indian Cases, ODI, London, UK.

Feldman, S. D., McClain and Palmer, K. (1976). Sources of Structural Change in the USA, 19631978. An Input- Output Approach. The Review of Economics and Statistics 69(3) 503510.

Fred-Mensah, B. K. (1999). "Capturing ambiguities: communal conflict management alternative in Ghana," World Development, vol. 27 (6): 951-965.

Goes, J., \& Marylin, K. S. (2013). Dissertation and Scholarly Research; Recipes for Success. Seattle, WA: Dessertation Success LLC.

GoK. (1965) African socialism and its application to planning in Kenya (No. 10). Govt. Printer.

GOK. (2016). National Spatial Plan 2015-2045, pp 3 historical background pre-independence planning Swynnerton plan of 1954 failures. Government printer

GOK. (2013). Baringo County CIDP, 2018-2022. County integrated development plan. County Government of Kenya

GoK. (1954), A Plan to intensify agriculture in Kenya. Government Printer, Nairobi, 1954.

Gosh, A. (1958). Input-output Approach in an Allocation System Economical 25(97) 58-67.

Greiner, C. (2013). "Guns, Land and Votes: cattle Rustling and the Politics of Boundary- (Re) making in Northern Kenya: African Affairs

Greiner, C. (2017). "Pastoralism and land Tenure Change in Kenya: The Failure of Customary Institutions". Development and Change 48 (1).

Greiner, C., Álvarez, M., \& Becker, M. (2013). From Cattle to Corn: Attributes of Emerging Farming Systems of Former Pastoral Nomads in East Pokot, Kenya. Society and Natural Resource 26 (12)

Gujarati, D., \& Porter, D. C. (2009). Basic Econometric. Fifth Edition, Mc Graw- Hill.

Guo, J., \& Planting, M. A. (2000). Using Input-output Analysis to Measure US Economic Structural Changes Over 24 years. Bureau of Economic Analysis working paper 1. 
Greiner, C. (2013). "Guns, Land and Votes: cattle Rustling and the Politics of Boundary- (Re) making in Northern Kenya: African Affairs

Greiner, C. (2017). "Pastoralism and land Tenure Change in Kenya: The Failure of Customary Institutions." Development and Change 48 (1).

Greiner, C., Álvarez, M., \& Becker, M. (2013). From Cattle to Corn: Attributes of Emerging Farming Systems of Former Pastoral Nomads in East Pokot, Kenya. Society and Natural Resource 26 (12)

Hahn, M. B., Riederer, A. M., Foster, S. O. (2009). The Livelihood Vulnerability Index: Pragmatic Approach to assessing risks from climate variability and change. A case of study in Mozambique. J Global Environ. Change 19 (1) 74-88

Heyer, J. (1981). Rural Development in Tropical Africa. London: Macmillan.

Huntington, H. P., Gearheard, S., Mahoney, A. R., \& Salomon, A. K. (2011). Integrating traditional and scientific knowledge through collaborative natural science field research: Identifying elements for success. The Arctic, 437-445.

Issac \& Michael. (1981). Education Research. An Introduction (4th Ed). New York. Longman Publishers.

Kaguru, J. M. (2018). Towards Effective Commissions of Inquiry in Kenya: a Review of the Commissions of Inquiry Act in Light of the Constitution of Kenya 2010 University of Nairobi (Doctoral dissertation, University of Nairobi).

Kameri-Mbote, P. (2016). Kenya Land Governance Assessment Report: World Bank Group

Kanji, N., MacGregor, J., Tacoli, C. (2005). Understanding market-based livelihoods in a globalizing world: combining approaches and methods. International Institute for Environment and Development (IIED).

Khamisi, J. (2018). Kenya: Looters and Grabbers: 54 years of corruption and plunder by the elite, 1963-2017. Plano, Texas, USA: Jodey Book Publishers

Kimberlin, C. L., \& Winterstein, A. G. (2008). Validity and reliability of measurement instruments used in research. American journal of health-system pharmacy, 65(23), 2276-2284.

Kogi, M. G. (2017). Curbing the individualization of community land rights in Kenya.

Kothari, C. K. (2014). Research methods and Techniques. New Delhi: New age International (P) Ltd.

Krantz, O. (2019). One and a Half Millennium of Economic Change in Sweden.

Leo, C. (1981). 'Who Benefited from the Million-Acre Scheme? Towards a Class Analysis of Kenya's Transition to Independence'. Canadian Journal of African Studies 15(2).

Leo, C. (1984). Land and Class in Kenya. Toronto: University of Toronto Press.

Leontief, W. (1936). 'Quantitative Input-Output Analysis and National Accounts. The Review of Economic Statistics 49(3) 412-419.

Leontief, W. (1970). Environmental Repercussions and the Economic Structure: An InputOutput Approach. The Review of Economic Statistics 53(3) 262-271.

Lewis, P. E. T., Martin, W. J., \& Savage, C. R. (1988). 'Capital Investment in Agricultural Economy Quarterly Review Rural Economy.

Little, P. D., \& McPeak, J. G. (2018). Mobile peoples, contested borders: land use conflicts and resolution mechanisms among Borana and Guji Communities, Southern Ethiopia. World Development, 103, 119-132. 
Luedeling, E., Lanzanova, D., Muchiri, C., Shepherd, K. D., Rosenstock, T. S., Krawinkel, M., \& Whitney, C. W. (2018). Probabilistic decision tools for determining impacts of agricultural development policy on household nutrition. Earth's Future, 6(3), 359-372.

Mc Fadden, D., \& Train, K. (2000). Mixed MNL Models for Discrete Response. Journal of Applied Econometrics.

Maddala, G. S. (1983). Methods of estimation for models of markets with bounded price variation. International Economic Review, 361-378.

Miernyk, W., \& Rose, A. (1989). Input-Output Analysis. First fifty years Economic System Research 1 (2) 229-272.

Michael, P. T., \& Smith, S. (2015). Economic Development Washington DC, Washington University Press

Migot-Adhola, S. E., and Little, P. D. (1981). Evolution of Policy Towards the Development of Pastoral Areas in Kenya. Paper presented at the Conference held in Nairobi, Kenya.

Migot-Adholla, S., \& Place, F. (1998). "The economic effects of land registration on smallholder farms in Kenya: evidence from Nyeri and Kakamega districts," Land Economics, vol. 74 (1): 360-373.

Miller, R. E. (2009). Input-Output Analysis. Foundations and Extensions. Volume 2 Cambridge University Press.

Mingate, F. L. (2012). Potential for Co-management Approaches to Strengthen Livelihoods of Forest-Dependent Communities: A Case Study of the Arabuko-Sokoke Forest Reserve, Kenya.

Moyo, S. (1995). The land question in Zimbabwe (p. 3). Harare: Sapes Books.

Mugabe, J., \& Ogolla, B. D. (1996). 'Land Tenure Systems and Natural Resources Management. In J K Coetzee, J Graaff, F Hendricks \& G Wood (eds). Development, Theory, Policy and Practice. Cape Town: Oxford University Press.

Ndungu Report. (2006). Report of the Commission of Inquiry into the Illegal/Irregular Allocation of Public Land: Republic of Kenya.

Njonjo Report. (2002). Report of the Commission of Inquiry into the Land Law System of Kenya: Republic of Kenya.

Nyandimo, J. A. (2011). ICT and Public Procurement in Kenya. Unpublished MBA Thesis, University of Nairobi.

Obeng-Odoom, F. (2012). Land reforms in Africa: Theory, practice, and outcome. Habitat international, 36(1), 161-170.

Ochieng, W. (1995). Themes in Kenyan History. Nairobi: Heinemann.

Odote, C. (2013). The dawn of Uhuru? Implications of constitutional recognition of communal land rights in pastoral areas of Kenya. Nomadic Peoples, 17(1), 87-105.

Ogolla, B., \& Mugabe, J. (2016) Land tenure systems and natural resource management. In Juma, C. and Ojwang", J., editors, in land we trust: Environment, private property and

Okoth-Ogendo, H. W. O. (1995), Tenants of the Crown: The evolution of the agrarian law and Institutions in Kenya, Nairobi eds.

Okoth-Ogendo, H., \& Oluoch-Kosura, W. (1995), Final report on land tenure and agricultural development in Kenya. Nairobi: The Ministry of Agriculture, Livestock Development and Marketing, Government of the Republic of Kenya and the Royal Netherlands Embassy.

Okoth-Ogendo, H. W. O. (1998). The Perils of Land Tenure: The Case of Kenya. Tokyo: United Nations University Press.

Olayide, S. O., \& Heady, E. O. (1982). Introduction to agricultural production economic: principles and application 
Ondiege, P. (1996). 'Land Tenure and Soil Conservation. In J K Coetzee, J Graaff, F Hendricks \& G Wood (eds). Development, Theory, Policy and Practice. Cape Town: Oxford University Press.

Orodho, A. J. (2003). Essentials of Educational and Social Science Research Methods: Masola Publishers.

Oso \& Owen. (2008). Data Collection Instruments. Significance of a series of questions

Österberg, T. (2001, October). What is an appropriate cadastral system in Africa? In Proceedings FIG/UNCHS international conference on spatial information for sustainable development (pp. 2-5).

Otsuka, K., and Place, F. (2001). Land Tenure and Natural Resource Management: a Comparative Study of Agrarian Communities in Asia and Africa, Baltimore: 17 Johns Hopkins University Press.

Pan, W., Jianzhong, Y., Xiaobo, H. (2019). Determinants of Livelihood Choice and Implications for targeted poverty reduction policies: a case study in the YNL river region, Tibetan Plateau. Journal of Ecological Indicators.

Pallant, J. (2011). SPSS Survival Manual 4th edition: A step by step guide to data analysis using SPSS version 18. Maidenhead, Berkshire: Open University Press. Retrieved on from http://www. allenandunwin. com/spss.

Park, J. Y. (2006). The supply Driven input-output Model: re-interpretation and Extension. Open University Press.

Pimentel, D., Berger, B., Filiberto, D., Newton, M., Wolfe, B., Karabinakis, E., \& Nandagopal, S. (2004). Water resources: agricultural and environmental issues. Bioscience, 54(10), 909-918.

Pinckney, T., \& Kimuyu, P. (1994). "Land tenure reform in East Africa: good, bad, or unimportant?" Journal of African Economies, vol. 3 (1): 1-28.

Pindyck, S., \& Rubinfeld, L. (1998). Econometric models and economic forecasts. United States of America: McGraw-Hill, Inc.

The Republic of Kenya. (2016). National Spatial Plan 2015-2045, Optimal Productivity, Sustainability, Efficiency and Equity in the use of our Land and Territorial Space, Government printer

The Republic of Kenya. (2013). Baringo County CIDP, 2018-2022. County integrated development plan. County Government of Kenya

The Republic of Kenya. (2013). Wayumba, G. (2017). A Review of Recent Land Policy Developments in Kenya.

The Republic of Kenya. (1954), The Swynnerton Plan of 1954: A Plan to intensify agriculture in Kenya. Government Printer, Nairobi, 1954.

Robson, C., \& McCartan, K. (2011). The analysis and interpretation of qualitative data. RealWorld Research. 3rd ed. Padstow: Wiley.

Rola-Rubzen, M. F., Hardaker, J. B., \& Dillon, J. L. (2001). Agricultural economists and world poverty: progress and prospects. Australian Journal of Agricultural and Resource Economics, 45(1), 39-66.

Rutten, M. (2010) Land reform in Africa: Lessons from Kenya. In Naerssen, T., Rutten, M. and Zoomers, A, editor, In: The diversity of development, Assen: Van Gorcum.

The Sahel. New York: Macmillan Press Limited.

Scoones, I. (1998). Sustainable rural livelihoods: A framework for analysis.

Shafi, M. (1984). "Agricultural productivity and regional Imbalances, Concept Publishing Company, New Delhi 
Shipton. (1998). "The Kenya land tenure reform: misunderstandings in the public creation of private property," in R.E. Downs and S.P. Reyna (eds.) Land and Society in Contemporary Africa, Hanover and London, University Press of New England.

Shivji, I. G. (1998). Not yet democracy: reforming land tenure in Tanzania. IIED.

Singh, A. S., \& Masuku, M. B. (2013). Fundamentals of applied research and sampling techniques. International journal of medical and applied sciences, 2(4), 124-132.

Singh, P. K., Hiremath, B. N. (2010). Sustainable livelihood security index in a developing country: a tool for development planning. Journal of Ecology. Indic 10 (2) 442-451.

Soini, E. (2005). Land use patterns and livelihood dynamics on the slopes of Mt Kilimanjaro, Tanzania J. Agric. Syste.85 (3) 306-323.

Syagga, P. (2006) Land ownership and use in Kenya: Policy prescriptions from an inequality perspective. Readings on Inequality in Kenya: Sectoral Dynamics and Perspectives, 289.

Ten Raa, T. (2005). The Economics of Input-Output Analysis. Cambridge University Press.

Thuo, A. D. M. (2013). Genealogy of Land Ownership, Use and Management Problems in Kenya During the Pre-August, 2010 Constitution Period. A Review. International Journal of Engineering Research \& Technology, ISSN:2278-0181. Vol.2 Issue8, August 2013.

Thurston, A. (1987) Smallholder agriculture in colonial Kenya. The official mind and the Swynnerton Plan. Cambridge, Reino Unido: Cambridge African Monographs.

Townsend, R. F., Ceccacci, I., Cooke, S., Constantine, M., \& Moses, G. (2013). Implementing agriculture for development: World Bank Group agriculture action plan (20132015) (No. 77911, pp. 1-132). The World Bank.

Tsoukalas, J. (2011). Input-Output Inventories in the UK. Journal of the Royal Statistical Society 78(3) 460-479.

Van Donge, J. K. (1999). "Law and order as a development issue: land conflicts and the creation of social order in Southern Malawi," Journal of Development Studies, vol. 36 (2): 373-399.

Van Loon, G. W., Patil, S. G., \& Hugar, L. B. (2005). “Agricultural Sustainability; Strategies for Assessment. SAGE Publication, New Delhi

Wakoko, V. (2012). The evolution of Land Law in Kenya. URL: https://www. Academia. Edu/8972722/The_Evolution_of_Land_Law_In_Kenya (05.09. 2017).

Wanjala, S. (1996). 'Recurrent Themes in Kenya's Land Reform Discourse since Independence.' Presented at the Southern and Eastern Regional Conference on Experiences, Perspectives and Strategies on Land Rights in Rural and Urban Settings, Johannesburg

Wanyeki, L. M. (eds.) (2003). Women and Land in Africa: Culture, Religion and Realizing Women's Rights, London: Zed Books.

Wanyonyi, A., Nyadimo, E., \& Kariuki, J. (2015). Land Tenure Security in Kenya (M. Kirk Ed. Report 3, 2015 ed.). UN Nairobi: UON, Publishing Services Section, Nairobi, ISO 14001:2004 certified.

Warren, C. (2005). Community mapping, local planning and alternative land use strategies in Bali. Geografisk Tidsskrift-Danish Journal of Geography, 105(1), 29-41.

Wooldridge, J. W. (2002). Econometric Analysis of Cross Section and Panel Data. Cambridge, Massachusetts: The MIT Press.

Yamano, T., \& Jayne, T. S. (2004). "Measuring the impact of working-age adult mortality on small-scale farm households in Kenya," World Development, vol. 32 (1): 91-119.

Zohrabi, M. (2013). Mixed-Method Research: Instruments, Validity, Reliability and Reporting Findings. Theory \& practice in language studies, 3(2). 